Jurnal Laut Khatulistiwa, Vol. 3 No. 3 (Oktober, 2020), Hal. 97-104.

\title{
Kelimpahan dan Keanekaragaman Gastropoda di Kawasan Mangrove Desa Bakau Besar Laut Kabupaten Mempawah
}

\section{Abudance and diversity of gastropoda in mangrove area bakau besar laut village Mempawah regency}

\author{
Atnsari $\mathbf{1}^{*}$, Anthoni B. A1, Shifa Helena ${ }^{1}$ \\ ${ }^{1}$ Laboratorium Ilmu Kelautan, FMIPA Universitas Tanjungpura, Pontianak, Indonesia \\ ${ }^{*}$ E-mail : atnasari.kelautan@gmail.com \\ Received : 4 Oktober 2020; Accepted : 22 Oktober 2020 \\ Published : 30 September 2020 (c) Author(s) 2020. This article is open access
}

\begin{abstract}
Mangrove forests contribute greatly to organic matter which is very important as a source of energy for biota such as gastropods. The research aims to determine the abundance and diversity of gastropods in the Mangrove Area of the Bakau Besar Laut Village of Mempawah Regency in June 2019. Determination of sampling stations were done by purposive sampling method from 3 stations based on the environmental base that represents residential areas, ecotourism and ponds. The results of that research was found as many as 7 species of gastropods, namely Cerithidea cingulata, Cerithidea obtussa, Nerita violacea, Cerithidea weyersi, Littoria scabra, Strombus mutabilis and Littoria undolata. The highest abundance value in station I was Cerithidea Cingulata with (63 ind $/ \mathrm{m}^{2}$ ), in station II the highest gastropod abundance was Cerithidea cingulata (89 ind $\left./ \mathrm{m}^{2}\right)$ and station III Cerithidea obtussa with value (25 ind $\left./ \mathrm{m}^{2}\right)$. Diversity index ( $\left.\mathrm{H}^{\prime}\right)$ ranges from 0.60 to 1.18 are categorized as moderate, uniformity index (E) ranges from 0.54 to 0.88 as uniform, and dominance index (D) from 0.37 to 0.67 categorized as moderate.
\end{abstract}

Keywords : gastropoda, abudance, diversity

\section{Abstrak}

Hutan mangrove memberikan kontribusi besar terhadap bahan organik yang sangat penting sebagai sumber energi bagi biota seperti gastropoda. Penelitian ini bertujuan untuk mengetahui kelimpahan dan keanekaragaman gastropoda di Kawasan Mangrove Desa Bakau Besar Laut Kabupaten Mempawah Pengambilan sampel pada juni 2019. Penentuan stasiun pengamatan menggunakan purposive sampling terdiri dari 3 stasiun berdasarkan zona lingkungan yang mewakili wilayah pemukiman, ekowisata dan tambak. Hasil penelitian mendapatkan gastropoda sebanyak 7 spesies yaitu, Cerithidea cingulata, Cerithidea obtussa, Nerita violacea, Cerithidea weyersi, Littoria scabra, Strombus mutabilis, dan Littoria undolata. Nilai kelimpahan tertinggi pada stasiun I adalah Cerithidea cingulata dengan (63 ind $\left./ \mathrm{m}^{2}\right)$, pada stasiun II kelimpahan gastropoda tertinggi adalah Cerithidea cingulata (89 ind $/ \mathrm{m}^{2}$ ) dan stasiun III Cerithidea obtussa dengan nilai $\left(25 \mathrm{ind} / \mathrm{m}^{2}\right)$. Nilai indeks keanekaragaman $\left(\mathrm{H}^{\prime}\right)$ berkisar $0,60-1,18$ dikategorikan sedang, nilai indeks keseragaman (E) berkisar 0,54-0,88 dikategorikan seragam, dan nilai indeks dominansi (D) 0,37-0,67 dikategorikan sedang.

Kata kunci : gatropoda, kelimpahan, keanekaragaman

\section{Pendahuluan}

Hutan mangrove merupakan salah satu ekosistem pesisir tropis dan sub tropis yang sangat dinamis dan mempunyai produktivitas yang tinggi. Hutan mangrove memberikan kontribusi besar terhadap bahan organik yang sangat penting sebagai sumber energi bagi biota yang hidup disekitarnya (Pakaya et al.,
2017). Ekosistem mangrove memiliki berbagai jenis flora dan fauna melalui dari mikrobia, protozoa hingga berukuran besar seperti gastropoda (Riyandi et al., 2017).

Gastropoda merupakan salah satu komunitas yang memiliki keanekaragaman yang tinggi. Keanekaragaman yang tinggi di dalam komunitas mengambarkan beragamnya 
komunitas tersebut (Pakaya et al., 2017). Keberadaan gastropoda sangat penting untuk menjaga keseimbangan ekologi di wilayah pesisir mangrove seperti di Desa Bakau Besar Laut Kabupaten Mempawah. Secara empiris wilayah pesisir merupakan salah satu tempat aktivitas ekonomi yang cukup kawasan pemukiman, parawisata, serta pembuangan limbah (Samir et al., 2016). Bentuk aktivitas ini secara langsung memberikan dampak terhadap perubahan lingkungan khususnya dibeberapa ekosistem mangrove di Desa Bakau Besar Laut. Kepadatan gastropoda di ekosistem mangrove sangat dipengaruhi oleh kegiatan yang terjadi pada ekosistem mangrove, dimana hal ini akan memberikan efek terhadap kelangsungan hidup gastropoda karena gastropoda cenderung hidup menetap dengan pergerakan yang terbatas. Sehingga gastropoda dapat di katakan sebagai bioindikator yang mempunyai kemampuan dalam merespon kondisi peairan secara terusmenerus (Samir et al., 2016).

Gastropoda mempunyai peranan yang sangat penting baik secara ekologi maupun ekonomi. Dari segi ekologi gastropoda berperan dalam mekanisme rantai makanan, perputaran hara dan kandungan hayati perairan. sedangkan dari segi ekonomi gastropoda memiliki harga jual, seperti cypraea, dimana cangkangnya digunakan untuk hiasan yang tentunya juga mempunyai harga jual. Selain itu, beberapa dari gasropoda juga di manfaatkan sebagai bahan makanan yang sangat mengandung nutrient, seperti jenis Cymbiola yang dagingnya diambil untuk komsumsi (Wahdaniar, 2016).

Desa Bakau Besar Laut Kabupaten Mempawah merupakan salah satu ekosistem mangrove alami yang selalu dimanfaatkan oleh masyarakat setempat untuk menunjang kebutuhan hidup seperti, kegiatan pertambakan, ekowisata dan kawasan industri. Aktivitas ini memberi dampak negatif terhadap perubahan lingkungan dan biota yang hidup disekitar mangrove. Kelimpahan dan keanekaragaman dari gastropoda dapat digunakan sebagai indikator adanya tekanan ekologi yang terjadi pada ekositem mangrove. Oleh karena itu berdasarkan hal tersebut maka perlu adanya penelitian terhadap kelimpahan dan keanekaragaman dari gastropoda di kawasan pemukiman, ekowisata dan tambak yang ada pada ekosistem mangrove di Desa Bakau Besar Laut Kabupaten Mempawah Kalimantan Barat.

Hal tersebut yang mendasari perlu dilakukan penelitian untuk mengetahui kelimpahan dan keanekaragaman gastropoda dengan hubungan lokasi pemukiman, ekowisata dan tambak di kawasan mangrove Desa Bakau Besar Laut Kabupaten Mempawah.

\section{Metodologi Penelitian}

\subsection{Waktu dan Lokasi Penelitian}

Pengambilan data Penelitian ini dilaksanakan pada bulan Juli 2019 di Kawasan Hutan Mangrove Desa Bakau Besar Laut, Kabupaten Mempawah. Analisis substrat



Gambar 1. Lokasi pengambilan sampel 
dilakukan di Laboratorium Mekanika Tanah, Fakultas Teknik, Universitas Tanjungpura, Pontianak, Provinsi Kalimantaan Barat. Peta lokasi penelitian dapat dilihat pada Gambar 1. Stasiun I berada di dekat pemukiman, stasiun II berada di dekat aliran sungai, stasiun III berada di mangrove alami dan stasiun IV berada di dekat tambak. Transek dibuat pada setiap stasiun yang ditarik secara tegak lurus dari garis pantai ke arah daratan.

\subsection{Pengambilan Sampel}

Masing-masing stasiun dibuat 1 garis transek sepanjang $23 \mathrm{~m}$ searah bibir pantai didaerah tertidal. Setiap transek terdiri dari 3 plot dengan ukuran $1 \mathrm{x} 1 \mathrm{~m}$ dan jarak antar plot $10 \mathrm{~m}$. Pengambilan data sampel gastropoda dilakukan saat kondisi surut dan tidak hujan. Sampel yang berada diatas substrat maupun yang menempel pada akar mangrove (berada di dalam mangrove) diambil seluruhnya diambil menggunakan tangan. Sampel gastropoda di setiap plot dihitung jumlahnya kemudian diawetkan menggunakan alkohol $70 \%$ dimasukan ke kantong sampel dan diberi tanda menggunakan kertas label (Selviani, 2018). Sampel gastropoda diidentifikasi dengan menggunakan buku identifikasi. Data yang diperoleh diolah dengan menghitung kelimpahan $(\mathrm{K})$, indeks keanekaragaman $\left(\mathrm{H}^{\prime}\right)$, indeks keseragaman (E), indeks dominansi (D), frekuensi (F), dan indeks nilai penting (INP).

Parameter lingkungan yang diukur dalam penelitian ini adalah suhu, salinitas, $\mathrm{pH}$, dan substrat. Pengambilan sampel substrat dilakukan untuk mengetahui tipe substrat, diambil pada setiap stasiun dengan menggunakan metode coring dengan pipa PVC dengan diameter $7,5 \mathrm{~cm}$. Sampel substrat diambil pada plot dengan kedalaman $15 \mathrm{~cm}$, selanjutnya dianalisis dengan metode hidrometer di laboratorium Mekanika Tanah, Universitas Tanjungpura.

\section{Hasil dan Pembahasan}

Gastropoda yang terdapat di perairan desa bakau besar laut sebanyak 7 spesies yaitu Cerithidea cingulata, Cerithidea obtussa, Nerita violacea Cerithidea weyersi, Littoria Scabra, Strombus mutabilis dan Littoria Undolata. Kelimpahan gastropoda di peraiaran desa bakau besar laut dari data kelimpahan yang didapat pada penelitian ini. Secara umum kelimpahan total gastropoda yang tertinggi terdapat pada stasiun II dan terendah pada stasiun III. Nilai kelimpahan (K) dan kelimpahan relatif (KR) di stasiun I.

Tingginya kelimpahan C.cingulata disebabkan karena jenis ini mendominansi habitat mangrove sehingga kelimpahannya cukup tinggi. Jenis ini cukup mendominansi dibandingkan beberapa jenis lainnya dimana spesies tersebut merupakan gastropoda yang mempunyai kemampuan adaptasi yang tinggi terhadap perubahan lingkungan di habitat mangrove yang disebabkan suhu, substratnya yang pasir berlanau sehingga mampu menyediakan bahan organik yang banyak sebaga makanannya. Sementara itu rendahnya kelimpahan pada N.violacea disebabkan oleh kondisi substrat, dimana substrat kasar lebih mudah melepas bahan organik dibandingkan substrat halus sehingga subsrat sangat



Gambar 2. Pembuatan Transek dan Plot pada Lokasi Penelitian 
berpengaruh terhadap perkembangan komunitas gastropoda.

C.weyersi merupakan kelimpahan terbanyak yang ditemukan dikarenakan spesies tersebut memiliki sebaran yang luas, yakni mempunyai tingkat kehadiran lebih merata pada daerah ekowisata sehingga lebih banyak ditemui. Selain itu terdapat spesies L.scabra yang jumlahnya cukup banyak dengan nilai 29 ind/m3 dan nilai KR 10,35\%. Dibandingkan spesies lain L.scabra ditemukan di lokasi Kawasan Mangrove Sungai Nyirih dengan penelitian Lina (2015), spesies L.scabra ditemukan pada stasiun II 15 ind $/ \mathrm{m} 3$. Spesies L.undolata dengan nilai $12 \mathrm{ind} / \mathrm{m} 3$ dan nilai KR $4,285 \%$. Sedangkan spesies S.mutabilis nilai terendah yang didapatkan yaitu nilai 8 ind $/ \mathrm{m} 3$ dan nilai KR 2,857\%. Rendahnya kelimpahan pada S.mutabilis disebabkan oleh kondisi substrat pada stasiun II adalah pasir berlanau dan juga di pengaruhi faktor suhu suatu organisme. (Yanto, 2016). Kisaran suhu di stasiun II $31^{\circ} \mathrm{C}$ yang terdapat pada setiap pengamatan merupakan kisaran suhu yang mampu mendukung kehidupan gastropoda meski pun kelimpahan spesies S.mutabilis rendah.

C.obtussa disebabkan memiliki substrat pasir berlanau sehingga memiliki cadangan makanan yang cuku bagi gastropoda, serta memiliki parameter suhu air $31^{\circ} \mathrm{C}, \mathrm{pH} 7,9$ dan salinitas $20 \%$. Selain itu juga dipengaruhi oleh substrat pada stasiun III, karena pada dasarnya substrat memiliki kandungan bahan organik sebagai cadangan makanan bagi gastropoda. Sedangkan rendahnya kelimpahan spesies C.weyersi disebabkan adanya aktifitas manusia seperti pengolahan tambak ikan disekitar kawasan mangrove sehingga mempengaruhi kehidupan biota pada stasiun II dan tidak banyaknya bebatuan untuk menempel sehingga kelimpahan gastropoda pada spesies C.weyersi rendah.

Indeks keanekaragaman tertinggi pada stasiun II yaitu, 1,18 dengan ditemukan 5 spesies. Nilai indeks keanekaragaman ini dikategorikan sedang, karena masih berada pada kisaran 1-3. Berdasarkan Tabel 4.3, jumlah individu yang di temukan pada stasiun II sebanyak 280. Tinggi nilai indeks keanekaragaman dapat dipengaruhi oleh berbagai macam faktor, antara lain jumlah spesies yang ditemukan dalam jumlah yang lebih banyak dari pada jenis yang lainnya (Romdhani et al., 2016). Tingginya nilai indeks keanekaragaman pada stasiun II karena adanya substrat di lokasi tersebut yaitu berlumpur dan stasiun II ini di lokasikan pada ekowisata. Tempat lokasi ini sudah lama tidak di kunjungi parawisata.

Nilai indeks keanekaragaman terendah ditemukan pada stasiun I dengan nilai 0,60 ditemukan 2 spesies dan stasiun III dengan nilai 0,61 ditemukan 4 spesies. Nilai indeks keanekaragaman tersebut dikategorikan rendah, karena <1. Berdasarkan Tabel 4.4 jumlah yang ditemukan pada stasiun I 78 individu dan stasiun III sebanyak 36 individu.

Tabel 1. Kelimpahan gastropoda di kawasan mangrove Desa Bakau Besar Laut pada Stasiun I

\begin{tabular}{ccc}
\hline Nama Spesies & K (Ind/M $\left.\mathrm{M}^{2}\right)$ & KR (\%) \\
\hline Cerithidea cingulata & 63 & 80,76 \\
Cerithidea obtussa & 11 & 14,10 \\
Nerita violacea & 4 & 5,128 \\
\hline
\end{tabular}

Tabel 2. Kelimpahan gastropoda di kawasan mangrove Desa Bakau Besar Laut pada Stasiun II

\begin{tabular}{ccc}
\hline Nama Spesies & K (ind $\left./ \mathrm{m}^{2}\right)$ & KR $(\%)$ \\
\hline Cerithidea cingulata & 89 & 31,78 \\
Cerithidae weyersi & 142 & 50,71 \\
Littoria scabra & 29 & 10,35 \\
Strombus mutabilis & 8 & 2,857 \\
Littoria undolata & 12 & 4,285 \\
\hline
\end{tabular}

Keterangan: $\mathrm{K}=$ Kelimpahan

$\mathrm{KR}=$ Kelimpahan Relatif 
Rendahnya indeks keanekaragaman Menurut Shalihah (2017), menyatakan nilai keanekaragaman yang rendah disebabkan karena faktor fisika-kimia terhadap perubahan lingkungan yang menyebabkan jumlah spesies yang didapat sedikit. Nilai keanekaragaman yang rendah menandakan ekositem mengalami tekanan atau kondisinya menurun (Ariska, 2012). Keanekaragaman jenis rendah ini dapat disebabkan karena lokasi yang terdapat pemukiman dan tambak udang yang kemungkinan membuang limbahnya ke muara tersebut. Pada kondisi seperti ini hanya gastropoda yang mempunyai kisaran penyebaran yang luas mendominasi di ketiga stasiun pengamatan.

Berdasarkan tabel 4.5 diketahui bahwa nilai indeks keseragaman pada stasiun I hingga stasiun III bervariasi yaitu berkisaran 0,540,88. Menurut Odum (1993), indeks keseragaman (E) berkisar 0,0-1,0. Jika nilai keseragaman yang diperoleh mendekati nilai 1 maka menunjukan komposis individu tiap spesies yang terdapat dalam suatu komunitas berada dalam kondisi yang relatif baik, yaitu penyebaran tiap jenis relatif sama atau seragam walaupun beberapa jenis gastropoda ditemukan dalam jumlah yang besar dibandingkang dengan jenis yang lainnya (Saptarini, 2010).

Indeks keseragaman tertinggi ditemukan pada stasiun III sebesar 0,88 dan stasiun II sebesar 0,7. Hal ini menunjukan bahwa keseragaman gastropoda ini dikategorikan tinggi karena nilai stasiun II dan III mendekati nilai satu. Indeks nilai keseragaman menunjukan bahwa sebaran biota merata dan nilai stasiun II dan III menunjukan bahwa antar spesies relatif merata atau jumlah indivudu masing-masing spesies relatif sama (Sapriyan, 2016). Nilai indeks keseragaman terendah ditemukan pada stasiun I yaitu 0,54. Rendahnya keseragaman pada stasiun I disebabkan kandungan substrat lanau berpasir. Nilai indeks keseragaman pada stasiun I dikategorikan rendah karena nilai indeks ini mendekati nilai 0 sebaran jenis tidak merata atau terdapat yang mendominansi.

Berdasarkan nilai indeks dominansi (D) gastropoda di Kawasan Mangrove Desa Bakau Besar pada Tabel 4.5, memiliki nilai yan bervariasi yaitu 0,37- 0,67. Menurut Odum (1993), jika jumlah individu tiap jenis tidak sama dan ada kecenderungan dominansi. Indeks dominansi untuk menghitung adanya spesies tertentu yang mendominansi suatu komunitas gastropoda. Nilai indeks dominansi semakin mendekati 1, maka semakin tinggi tingkat dominansi spesies tertentu, sebaliknya bila nilai mendekati 0 berarti tidak ada jenis yang mendominansi. Hasil pengamatan menunjukan bahwa nilai indeks dominansi pada Kawasan Mangrove Desa Bakau Besar dalam kategori dominansi rendah dan sedang.

Indeks dominansi sedang ditemukan pada stasiun I dengan nilai 0,67 dan stasiun III dengan nilai 0,57 . Nilai indeks ini menunjukan bahwa pada stasiun I dan III penelitian tidak terdapat jenis yang mendominansi jenis lainnya atau struktur komunitas dalam

Tabel 3. Kelimpahan gastropoda di kawasan mangrove esa Bakau Besar Laut pada Stasiun III

\begin{tabular}{ccc}
\hline Nama Spesies & K (ind $\left./ \mathrm{m}^{2}\right)$ & KR $(\%)$ \\
\hline Cerithidea obtussa & 25 & 69,44 \\
Cerithidae weyersi & 11 & 30,55 \\
\hline
\end{tabular}

Keterangan: $\mathrm{K}=$ Kelimpahan

$\mathrm{KR}=$ Kelimpahan Relatif

Tabel 4. Indeks keanekaragaman, keseragaman dan dominansi gastropoda di Kawasan mangrove Desa Bakau Besar

\begin{tabular}{cccccc}
\hline Stasiun & Jumlah Spesies & Jumlah Individu & $\mathrm{H}^{\prime}$ & $\mathrm{E}$ & $\mathrm{D}$ \\
\hline I & 3 & 78 & 0,6 & 0,54 & 0,67 \\
II & 5 & 280 & 1,18 & 0,73 & 0,37 \\
III & 2 & 36 & 0,61 & 0,88 & 0,57 \\
\hline
\end{tabular}

Keterangan : $\mathrm{H}^{\prime}=$ Keanekaragaman, $\mathrm{E}=$ keseragaman, $\mathrm{D}=$ dominansi 
Jurnal Laut Khatulistiwa, Vol. 3. No. 3 (Oktober, 2020), Hal. 97-104

Tabel 5. Nilai parameter lingkungan di kawasan mangrove Desa Bakau Besar Laut

\begin{tabular}{ccccl}
\hline Stasiun & Suhu $\left({ }^{\circ} \mathbf{C}\right)$ & pH & Salinitas (\%o) & Subtrat \\
\hline I & 30 & 7,7 & 25 & $\begin{array}{l}\text { Pasir } \\
\text { berlempung }\end{array}$ \\
II & 31 & 7,9 & 20 & $\begin{array}{l}\text { Lempung } \\
\text { berpasir }\end{array}$ \\
III & 33 & 8,2 & 25 & $\begin{array}{l}\text { Pasir } \\
\text { berlempung }\end{array}$ \\
\hline
\end{tabular}

keadaan stabil. Sehingga di dua stasiun tersebut tidak ada penguasaan habitat oleh jenis tertentu. Indeks dominansi terendah ditemukan pada stasiun II yaitu 0,37. Rendahnya nilai dominansi karena tidak adanya spesies yang mendominansi.

Adanya variasi suhu antar stasiun disebabkan oleh perbedaan waktu pengukuran, pengukuran dilakukan antara waktu 08.00-16.00. Kondisi ini menunjukan bahwa hutan mangrove Desa Bakau Besar masih mendukung kehidupan gastropoda. Rendahnya suhu pada stasiun I karena pengukurannya pukul 08.00 pagi. Sedangkan suhu tertinggi terdapat pada stasiun III yaitu $33{ }^{\circ} \mathrm{C}$. Tingginya suhu permukaan air pada stasiun III dapat disebabkan oleh keterbukaan perairan pada lokasi tersebut dan pengukurannya pkul 16.00. Semakin terbukanya suatu perairan dari lokasi mangrove, maka akan semakin cepat proses transfer panas cahaya matahari dibandingkan dengan daerah yang tidak mendapat transfer cahaya matahari (Sinaga and Riwayati., 1999; Magdalena, 2019). Menurut Ayunda (2011), perbedaan suhu antar stasiun pengamatan masih berada di kisaran normal bagi organisme akuatik. Pernyataan ini dibuktikan dengan kelimpahan spesies yang relatif hampir sama pada suhu rendah maupun tinggi. Kisaran suhu optimum untuk perkembangan dan reproduksi $0^{\circ} \mathrm{C}-48^{\circ} \mathrm{C}$ (Siwi et al., 2017). bahwa kisaran suhu yang ideal untuk pertumbuhan dan reproduksi gatropoda pada umumnya adalah $25^{\circ} \mathrm{C}-32^{\circ} \mathrm{C}$.

$\mathrm{pH}$ yang didapat dari hasil pengukuran dilapangan yaitu stasiun I berkisar 7,7, stasiun I adalah nilai terendah, stasiun II memiliki nilai 7,9 dan sedangkan stasiun III memiliki nilai pH tertinggi yang berkisar 8,2. Tinggi rendahnya $\mathrm{pH}$ merupakan faktor yang penting untuk mengontrol aktifitas dan distribusi organisme yang hidup di dalam perairan (Siwi et al., 2017). Hasil nilai pengamatan di Situ Agathis yaitu 7 dan gastropoda masih dapat hidup (Dermawan, 2010). Menurut Nuha (2015) besar $\mathrm{pH}$ air yang ideal untuk kehidupan gastropoda adalah berkisaran 6-8, karena pada kisaran tersebut menunjukan keseimbangan yang ideal antara oksigen dan karbondioksida serta berbagai mikroorganisme yang merugikan sulit berkembang. Sementara menurut Ernanto et al., (2010), kisaran pH yang dapat menunjang kehidupan organisme gastropoda berkisar 5-9.

Salinitas air di lingkungan mempengaruhi keseimbangan air dalam tubuh organisme, sehingga perubahan salinitas juga mempengaruhi mekanisme difusi dan osmosis (Siwi et al., 2017). Nilai salinitas yang terukur di setiap stasiun penelitian tidak jauh berbeda yaitu stasiun I $25 \%$, stasiun II dengan nilai $20 \%$ dan sedangkan stasiun III berkisar 25\%o. Hasil nilai pengamatan yang dilakukan di kawasan hutan mangrove segara anakan cilacap yaitu menunjukan sekitar 22,38-27,82 \%o (Pribadi et al., 2009). Berbeda lagi hasil pengamatan di ekosistem mangrove sungai Batang ogan kemiring yaitu $24 \%$, hal ini karena daerah lokasi penelitian merupakan daerah muara dan jarak dari semua stasiun tidak terlalu juah sehingga salinitas antara semua stasiun sama (Ernanto et al., 2010). Kisaran ini masih layak untuk kehidupan gastropoda, karena gastropoda masih mampu bertahan hidup dan berkembang pada daerah ini (Hasniar et al., 2013). Menurut Siwi et al., (2017) salinitas optimum untuk kehidupan gastropoda yaitu berkisar 5-75\% .

Tipe fraksi substrat kawasan mangrove Desa Bakau Besar memiliki fraksi substrat berjenis pasir berlempung, lempung berpasir dan pasir berlempung, ditemukan 7 spesies gastropoda. Substrat merupakan salah satu faktor ekologis utama yang mempengaruhi struktur komunitas dan kehidupan gastropoda. Substrat mempunyai peran penting bagi kehidupan gastropoda. Tekstur 
substrat merupakan tempat untuk menempel atau merayap dan berjalannya gastropoda. Substrat memiliki kandungan oksigen dan ketersediaan nutrien dalam sedimen (Sirih, 2016).

Kandungan fraksi pasir merupakan substra yang relatif besar dibandingan dengan substrat lempung yang halus, pada substrat berpasir terdapat pori udara yang mungkin terjadinya pencampuran yang intensif dengan air diatasnya. Pasir dibutuhkan dalam kehidupan gastropoda, yakni untuk memperbaiki aerasi (menyatu dengan debu) ketika gastropoda menyusup kedalam substrat (Payung, 2017).

\section{Kesimpulan}

Hasil kelimpahan gastropoda di kawasan mangrove Desa Bakau Besar Laut Kabupaten Mempawah yakni yang tertinggi pada stasiun I yaitu di kawasan pemukiman adalah C.cingulata dengan nilai $63 \mathrm{ind} / \mathrm{m}^{2}$, pada stasiun II di kawasan ekowisata adalah C.weyersi tinggi dengan nilai $142 \mathrm{ind} / \mathrm{m}^{2}$ dan pada stasiun III di kawasan tambak kelimpahan gastropoda yang tertinggi adalah C.obtussa dengan nilai $25 \mathrm{ind} / \mathrm{m}^{2}$. Keanekaragaman gastropoda di kawasan mangrove Desa Bakau Besar Laut Kabupaten Mempawah yakni pada Stasiun I sebesar H' 0,60, dan Stasiun III mencapai $H^{\prime}$ 0,61 dan termasuk kategori rendah. Sedangkan Stasiun II mencapai $\mathrm{H}^{\prime}$ 1,18 dan termasuk kategori sedang.

\section{Daftar Pustaka}

Ariska, S. D, 2012, Keanekaragaman dan Distribusi Gastropoda dan Bivalvia (Moluska) di Muara Karang Tirta Pangandaran, Institut Pertanian Bogor, Fakultas Matematika Dan Ilmu Pengetahuan Alam, Bogor, (Skripsi).

Ayunda, R., 2011, Struktur Komunitas Gastropoda pada Ekosistem Mangrove Gugus Pulau Pari, Kepulauan Seribu, Universitas Indonesia, Fakultas Matematika dan Ilmu Pengetahuan Alam, Depok, (Skripsi).

Dermawan, H., 2010, Studi Komunikasi Gastropoda di Situ Agathis Kampus Universitas Indonesia, Depok, Universitas
Indonesia, Fakultas Matematika dan Ilmu Pengetahuan Alam, Depok, (Skripsi).

Ernanto, R, Fitri. A dan Riris. A., 2010, Struktur Komunitas Gastropoda pada Ekosistem Mangrove di Muara Sungai Batang Ogan Komering Ilir Sumatera Selatan, J. Maspari. 1:73-78

Hasniar; Magdalena. L dan Dody. P., 2013, Biodiversitas Gastropoda di Padang Lamun Perairan Mara'Bombang Kabupaten Pinrang Sulawesi Selatan, J. Kel.Perikanan., 23:127-136.

Lina, F. L dan Andi. Z., 2015, Struktur Komunikasi Gastropoda di Ekosistem Mangrove Sungai Nyirih Kecematan Tanjung Kota, FIKP-UMRAH, Jurusan Manajemen Sumberdaya Perikanan, J. Perikanan. 1:1-15.

Mangdalena, W., 2019, Struktur Komunitas Siput Laut (Kelas Gastropoda Di Pesisir Dusun Karang Utara, Pulau Lemukutan, Universitas Tanjungpura, Fakultas Matematika dan Ilmu Pengetahuan Alam, Pontianak, (Skripsi).

Nento, R. Femy. S dan Siti. N., 2013, Kelimpahan Keanekaragaman dan Kemerataan Gastropoda di Ekosistem Mangrove Pulau Dudepo Kecematan Anggrek Kabupaten Gorontalo Utara, J. Ilmiah Perikanan Dan Kel., 1:41-47.

Nuha, U., 2015, Keanekaragaman Gastropoda pada Lingkungan Terendam POB Desa Bedona Kecematan Sayung Kabupaten Demak, Universitas Islam Negeri Walisongo Semarang, Fakultas Ilmu Takbijah dan Keguruan, Semarang, (Skripsi).

Odum, E,P., 1993, Dasar-Dasar Ekologi, Penerjemahan: Samingan, $\mathrm{T}$ dan $\mathrm{B}$, Srigandono, Gajahmada University Press, Yogyakarta.

Pakaya, F.; Abd H. O. dan Citra P., 2017, Keanekaragaman dan Kelimpahan Bivalvia pada Ekosistem Mangrove di Desa Mananggu Kecamatan Mananggu Kabupaten Boalemo, J. Ilmiah Perikanan dan Kelautan, 5:31-34.

Payung, W. R.,2017, Keanekaragaman Makrozoobentos (Epifauna) pada Ekosistem Mangrove di Sempadan Sungai Tallo Kota Makassar, Universitas Hasanuddin, Fakultas Ilmu Kelautan dan Perikanan, Makassar, (Skripsi). 
Pribadi, R. Retno. H. Chrisna. A. S., 2009, Komposisi Jenis dan Distribusi Gastropoda di Kawasan Hutan Mangrove Segara Anakan Cilacap, J. Kel. 14:102-111.

Riyandi, H. Indra J. Z dan Izmiarti, 2017, Diversitas Gastropoda pada Akar Mangrove di Pulau Sirandah, Padang, Sumatera Barat, J.Bio.UA. 5:34-40.

Romdhani, A. M.; Sukarsono dan Rr. E.S., 2016, Keanekaragaman Gastropoda Hutan Mangrove Desa Baban Kecamatan Gapura Kabupaten Sumenep Sebagai Sumber Belajar Biologi, J. Pendi. Bio. Indo. 2:161167.

Samir, Wa. N dan Romy K., 2016, Studi Kepadatan dan Pola Distribusi Bivalvia di Kawasan Mangrove Desa Balimu Kecamatan Lasalimu Selatan Kabupaten Buton, J. Manajemen sumber daya perairan, 1: 169-181.

Saptarini, D. Indah. T dan Mardian. A. H., 2010, Struktur Komunitas Gastropoda (Moluska) Hutan Mangrove Sendang Biru Malang Selatan, J. Bio. 1:1-16.

Sapriyan, Ha. K. dan susiana., 2016, Tingkat Keanekaragaman Jenis Gastropoda Pada Zona Intertidal Perairan Kampung Sungai Cenot Desa Mantang Baru Kecematan Mantang Kabupaten Bintan, Universitas Maritim Raja Ali Haji, Tanjung Pinang, Fakultas Ilmu Kelautan dan Perikanan, (Skripsi).

Selvianai., 2018, Keanekaragaman Makrozoobenthos di Kawasan Hutan Mangrove Desa Sungai Bakau Kecil Kabupaten Mempawah, J. Laut. Khatu. 1:6065.

Shalihah, H. N. Pujiono. W. P dan Niniek.W., 2017. Keanekaragaman Moluska Bedasarkan Tekstur Sedimen dan Kadar Bahan Organik pada Muara Sungai Betahwalang Kabupaten Demak, J. Saintek Perikanan. 13:58-64.

Sirih, R. H. H dan Asmawati. M., 2016, Kelimpahan Gastropoda pada Ekosistem Mangrove di Pantai Latawe Kecematan Napano Kosambi Kabutaten Muna Barat, J. Ampibi. 1:13-16.

Siwi, F. R.; Sudarmadji dan Suratno, 2017, Keanekaragaman dan Kepadatan Gastropoda di Hutan Mangrove Pantai Si Runtoh Taman Nasional Baluran, J. Ilmu Dasar. 18:119-124.
Wahdaniar, 2016, Keanekaragaman dan Kelimpahan Gastropoda di Sungai Je'neberang Kabupaten Gowa, UIN Alauddin Makasar, Fakultas Sains dan Teknologi, Makasar, (Skripsi).

Yanto, R., 2016, Ekosistem Gastropoda pada Ekosistem Mangrove Pantai Masiran Kabupaten Bintan, FIKP-UMRAH, J. Kel. 1:110. 